\title{
Phytotoxicity of Contaminated Sand Containing Crude Oil Sludge on Ludwigia octovalvis
}

\author{
Saja Radhi Nayyef Alanbary ${ }^{1,2}$, Siti Rozaimah Sheikh Abdullah ${ }^{1 *}$, \\ Israa Abdul Wahab Al-Baldawi', Hassimi Abu Hassan', \\ Nurina Anuar', Ahmad Razi Othman'1, Fatihah Suja' ${ }^{2}$ \\ 1 Department of Chemical and Process Engineering, Faculty of Engineering and Built Environment, Universiti \\ Kebangsaan Malaysia, 43600 UKM Bangi, Selangor, Malaysia \\ 2 Department of Civil and Structural Engineering, Faculty of Engineering and Built Environment, Universiti \\ Kebangsaan Malaysia, 43600 UKM Bangi, Selangor, Malaysia \\ ${ }^{3}$ Department of Biochemical Engineering, Al-Khwarizmi College of Engineering, University of Baghdad, \\ Baghdad, Iraq \\ * Corresponding author's e-mail: rozaimah@ukm.edu.my
}

\begin{abstract}
This present research work was conducted to determine the phytotoxic effects on tropical native plants, Ludwigia octovalvis, in order to assess its application for phytoremediation of crude oil sludge in contaminated sand. For this purpose of study, L. octavalvis plants were planted in containers containing different proportion of spiked real crude oil sludge in sand $(10 \%, 50 \%$, and $100 \%(\mathrm{v} / \mathrm{v}))$. Degradation of crude oil sludge by $L$. octovalvis was measured in terms of total petroleum hydrocarbons (TPH) and was compared with TPH degradation inside control crates without plants. The findings indicated that the average TPH removal after a prolonged 42-day exposure period was high. The degrees of TPH degradation were $67.0,42.4$ and $46.2 \%$ in sand spiked with real crude oil sludge at 10,50 and $100 \%$ respectively, whereas the degradation was only $34.7,29.1$ and $20.5 \%$ for the unplanted containers at the same respective proportions of crude oil sludge in sand. These findings give evidence that $L$. octovalvis has the capability to degrade hydrocarbons in crude oil sludge.
\end{abstract}

Keywords: phytotoxicity, Ludwigia octovalvis, total petroleum hydrocarbons, crude oil sludge, phytoremediation

\section{INTRODUCTION}

Crude oil or petroleum is a complex mixture of hydrocarbons of varying molecular weight and structure. This solid waste is usually generated from the petroleum industry mainly during its crude oil exploration, refining process, transportation and storage (Xu et al. 2009). Toxic and harmful chemicals inside crude oil sludge can threaten both the human life and the environment (Robertson et al. 2007; Phillips et al. 2009). Hydrocarbon content inside crude-oil sludge is normally measured as total petroleum hydrocarbon (TPH). There are many factors to be considered in treating organic pollution including the stability, evaporation, photolysis and adsorption to dead biomass of the chemicals, as well as the existence of miccroorganism (Cai et al. 2007). Various treatment methods for petroleum-contaminated soil, including physical, chemical and biological processes, have been established, including incineration, landfill, burning, solidification/stabilization, pyrolysis, photocatalysis, solvent extraction, chemical treatment and biodegradation (Hua et al. 2013). Phytoremediation, or plant-assisted approach, is a biological process that employs plants with the assistance of microbes to stabilize, extract, accumulate, degrade, transform and detoxify contaminants in various media (sediments, soils and water). It is a promising, efficient, cost-effective, engineering-economical, environmentally friendly, and alternative technology to 
remediate environmental contaminants. Several factors need to be considered when selecting plants for phytoremediation; native plants to the oil-contaminated area are preferable and should have high tolerance to the local climate conditions and contaminants (Liu et al. 2011). The degradation of hydrocarbons is affected by plant species characteristics. In addition, chemical characteristics of soil and the inhabitants of microorganism inside the soil itself can directly affect the performance of phytoremediation process as stated by Hanks et al. (2015) and Guo et al. (2012). The application of plant species to the bio-remediated sites that have oil-contaminated soil has been shown in several studies (Sanusi et al. 2016; AlBaldawi et al. 2014; Almansoory et al. 2019). According to Khan et al. (2013) and Sharonova (2012), the removal of hydrocarbons from soil through phytoremediation highly depends on the plants and their interaction with microorganism at the roots. Different plants have different capability towards the presence of hydrocarbons. Very high potential plants can resist and tolerate the hydrocarbon existence inside soil and simultaneously degrade the hydrocarbons with the aids of rhizosphere microbes. Roots release some compounds acting as inducers for microbes to degrade hydrocarbon and plant roots assist soil microorganisms to be tolerable to petroleum hydrocarbons (Cao et al. 2012). With the existence of hydrocarbons in soil, plant roots are induced to exudate chemicals that can enrich the growth of the soil microbes which finally be tolerant to the petroleum hydrocarbons. The capability of the microorganism inside the root zones to remediate hydrocarbons will determine the effectiveness of the hydrocarbon degradation process (Cao et al. 2012; Tang et al. 2011).

In this study, Ludwigia octovalvis plants have been described as a plant that can survive on a contaminated site containing hydrocarbons. According to Al-Mansoory et al. (2017), L. octovalvis is a good plant for contaminated sites in Malaysia. L. octovalvis is an aquatic fruticose shrub or perennial woody herb that can grow up to $2 \mathrm{~m}$ in height with $1 \mathrm{~cm}$ for the stem diameter. The plants are supported by long and taproots that grow under the soil surface. It is locally known as "Buyang samalam" and "Lakom ayer" in Malaysia and Indonesia. The aim of this study was to determine the effect of crude oil sludge on L. octovalvis by assessing hydrocarbon degradation via TPH measurement by this plant.

\section{MATERIALS AND METHOD}

\section{Characterization of crude oil sludge}

The raw crude oil sludge in this study was obtained from a contaminated site from a petroleum industry in Malaysia. The parameters analyzed from the extracted crude oil sludge include concentrations of TPH, BTEX, ammonia $\left(\mathrm{NH}_{3}-\mathrm{N}\right)$, nitrate $\left(\mathrm{NO}_{2}-\mathrm{N}\right)$, nitrite $\left(\mathrm{NO}_{3}-\mathrm{N}\right)$, and phosphate $\left(\mathrm{PO}_{4}{ }^{3-}\right)$, as well as $\mathrm{pH}$, as shown in Table 1 (Alanbary et al. 2018).

\section{Experimental phytotoxicity run}

The phytotoxicity study was executed in a greenhouse at Universiti Kebangsaan Malaysia. This phytotoxicity test was performed to determine the maximum TPH concentration in crude oil sludge that $L$. octovalvis can survive and resist in the contaminated medium. In the phytotoxicity experimental set-up, 13 containers made of glasses were prepared. Glass containers were used to reduce oil stick to the container walls. Each container, with dimensions $60 \times 30 \times 30 \mathrm{~cm}(\mathrm{~L} \times \mathrm{W} \times \mathrm{D})$, was filled first with $10 \mathrm{~cm}$ of gravel at the bottom layer and then another $10 \mathrm{~cm}$ of crude oil sludge as the top layer. The following four different concentrations of sludge were prepared: $0 \%(\mathrm{v} / \mathrm{v})$ as the control (100\% sand), $10 \%(10 \%$ sludge + $90 \%$ sand), $50 \%$ (50\% sludge $+50 \%$ sand), and $100 \%(\mathrm{w} / \mathrm{w})(100 \%$ sludge). Three replicates (R1, $\mathrm{R} 2$ and R3) were used at each concentration, with one container for a contaminant control without plants (CC), and also a container without crude oil sludge acted as a plant control (PC), as illustrated in Figure 1. Sand was used instead of sand to maximize the dependence of plants to grow based on available nutrients in crude oil sludge. Seeds of L. octavalvis obtained from a parent plant found growing at a contaminated site with crude oil sludge in Malaysia, were used to propagate the plants. In each container with different

Table 1. Characteristics of crude oil sludge

\begin{tabular}{|l|c|c|}
\hline \multicolumn{1}{|c|}{ Parameters } & Unit & Value \\
\hline TPH & $\mathrm{mg} / \mathrm{kg}$ & 14,700 \\
\hline BTEX & $\mathrm{mg} / \mathrm{kg}$ & 0.005 \\
\hline Ammonia $\left(\mathrm{NH}_{3}-\mathrm{N}\right)$ & $\mathrm{mg} / \mathrm{kg}$ & 4.09 \\
\hline Nitrate $\left(\mathrm{NO}_{2}-\mathrm{N}\right)$ & $\mathrm{mg} / \mathrm{kg}$ & 0.028 \\
\hline Nitrite $\left(\mathrm{NO}_{3}-\mathrm{N}\right)$ & $\mathrm{mg} / \mathrm{kg}$ & 4.7 \\
\hline Phosphate $\left(\mathrm{PO}_{4}{ }^{3-}\right)$ & $\mathrm{mg} / \mathrm{kg}$ & 2.09 \\
\hline $\mathrm{pH}$ & - & 6.7 \\
\hline
\end{tabular}




\begin{tabular}{|c|c|c|c|c|}
\hline $\begin{array}{l}\text { Sludge } \\
\text { concentration }\end{array}$ & R1 & R2 & R3 & CC \\
\hline $100 \%$ & 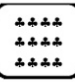 & 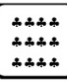 & 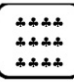 & \\
\hline $50 \%$ & 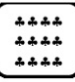 & 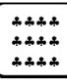 & 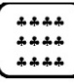 & \\
\hline $10 \%$ & 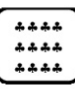 & 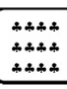 & 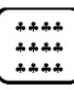 & \\
\hline $\begin{array}{l}0 \% \\
\text { (PC) }\end{array}$ & 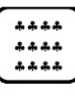 & & $*=\mathrm{Lr}$ & valvis \\
\hline
\end{tabular}

Figure 1 Experimental phytotoxicity set-up for Ludwigia octavalvis in crude oil sludge exposure (R1, R2, $\mathrm{R} 3$ = replicates with plants $; \mathrm{CC}=$ crude oil sludge without plants; $\mathrm{PC}=$ plant control without crude oil sludge)

proportions of crude oil sludge in sand $(10 \%$, $50 \%, 100 \% \mathrm{v} / \mathrm{v}), 12$ healthy L. octovalvis plants of 8-weeks old were planted in replicate containers (R1, R2 and R3). All the containers including the unplanted controls were watered at every alternate day to a fixed level of water for plant growth sustainability. Samplings of crude oil sludge in the rhizosphere inside each container were carried out on days $0,7,14,28,42$.

\section{Determination of the physicochemical properties}

An IQ 150 probe (IQ Scientific Instruments, UK) was used to record the physicochemical parameters of $\mathrm{pH}$ and temperature. The water inside the sand was sampled to record its $\mathrm{pH}$ value, while the temperature of the environment inside the greenhouse was recorded on each sampling day (Day 0, 7, 14, 28 and 42).

\section{Determination of anion and cation concentrations in crude oil sludge}

Anion and cation concentrations were determined to identify the changes in the plant biomass and to determine the cause of such changes. Anionic concentrations were determined from the sand or mixture of sand and sludge in the planted and unplanted glass containers. A sample of $5 \mathrm{~g}$ of sludge was obtained and mixed with $50 \mathrm{~mL}$ of distilled water in a shaker for $1 \mathrm{~h}$. After shaking, the mixture was filtered using a vacuum pump and filter paper (Whatman, England). Anions and cations from the filtered components of water were analyzed using an ion chromatogram (Metrohm 882 Compact IC plus, USA).

\section{Analysis of plant growth}

On each sampling day (Day 0, 7, 14, 28 and 42), one plant was harvested from each replicate container (R1, R2, and R2) and plant control (PC). The procedure starts by rinsing the whole plant with tap water, and then the excess water was absorbed using tissue papers. The stem height and the root length buried in the sludge were measured. The wet and dry weights of the leaves and stems (upper layer) were recorded gravimetrically according to a protocol by Ogbo et al. (2010). For the determination of dry weight, all of the plant part samples were dried in an oven (Memmert, Germany) at $70{ }^{\circ} \mathrm{C}$ for $72 \mathrm{~h}$ until it reached constant mass (Peng et al. 2009).

\section{Extraction of total petroleum hydrocarbons in sludge mixture}

Total petroleum hydrocarbons (TPH) in the samples were extracted using an ultrasonic solvent extractor following the method by Tang et al. (2012). All replicates of spiked medium were sampled on each sampling day. Approximately $10 \mathrm{~g}$ of each sample from each container was placed in a $100 \mathrm{~mL}$ flask on the same sampling day for all treatments and kept at 4 ${ }^{\circ} \mathrm{C}$ before the extraction process. Sludge samples were dried by mixing with sodium sulfate $\left(\mathrm{Na}_{2} \mathrm{SO}_{4}\right)$ and later placed in a $100 \mathrm{~mL}$ Schott bottle with $50 \mathrm{~mL}$ dichloromethane (DCM) (R\&M Chemicals, UK). The sample bottle was rotated in an ultrasonic cleaner (Thermo-10D, USA) for $30 \mathrm{~min}$ at $50{ }^{\circ} \mathrm{C}$. Glass wool was used to filter the supernatant and then it was concentrated by leaving it in a fume hood for 2-3 days 
to ensure the solvent totally evaporated, after which, $2 \mathrm{~mL}$ DCM was added, and the extracts were stored in gas chromatography vials for TPH analysis.

\section{Determination of TPH content}

A gas chromatography with a flame ionization detector (GC-FID) (Agilent Technologies, Mode17890A, GC System, U.K.) was calibrated to detect hydrocarbon content in the crude oil sludge. The sample extracts were analyzed by the GC-FID using a HP-5.5\% phenyl methyl siloxane column $(30 \mathrm{~m} \times 0.32 \mathrm{~mm}$ i.d. $\times 0.25 \mathrm{~mm})$ with helium as the carrier gas. The column temperature was fixed at $50{ }^{\circ} \mathrm{C}$ for $1 \mathrm{~min}$ and then increased at $15^{\circ} \mathrm{C}$ per min to $320^{\circ} \mathrm{C}$ for $10 \mathrm{~min}$. The determination of the TPH content in sludge mixture was determined using Eq. (1):

$\mathrm{TPH}$ concetration $(\mathrm{mg} / \mathrm{kg})=$

$$
=\frac{\text { GC-FID result }(\mathrm{mg} / \mathrm{L}) \times \mathrm{GC} \text { vial volume }(2 \mathrm{~mL})}{\text { Mass of soil }(\mathrm{g})}
$$

The percentage of TPH removal on each sampling day was calculated using Eq. (2):

$$
\text { Removal }(\%)=\frac{\mathrm{TPH}_{0}-\mathrm{TPH}_{\mathrm{SD}}}{\mathrm{TPH}_{0}} \times 100 \%
$$

where: $\mathrm{TPH}_{0}=$ total petroleum hydrocarbons on sampling day 0 , and

$\mathrm{TPH}_{S D}=$ total petroleum hydrocarbons on each sampling day.

\section{Statistical analysis of TPH removal}

The statistical analysis of TPH removal by plants was evaluated using SPSS version 21 (SPSS Inc., U.S.A.) to evaluate significant difference $(p<0.05)$ between the values. Differences in TPH removal between with plants and without plants treatments were statistically analyzed on each sampling day. All experiment run was conducted in triplicate.

\section{RESULTS AND DISCUSSION}

\section{Variation of $\mathrm{pH}$ and temperature}

During the 42 days of the experiment period, the recorded temperature changed from 27 to $29^{\circ} \mathrm{C}$ which is within $20-30^{\circ} \mathrm{C}$, stated as the optimum temperature for the hydrocarbon biodegradation in temperate countries as stated by Chan (2011). The $\mathrm{pH}$ ranged between 7.02 and 7.75 for containers with plants, and between 6.86 and 7.91 for containers without plants, indicating that $\mathrm{pH}$ did not fluctuate significantly during the experiments and that this $\mathrm{pH}$ range is most suitable for plant and microbe growth

\section{Plant growth response towards the crude oil sludge}

The nominal plant growth parameters were monitored on each sampling day during the prolonged 42-day exposure (Figure 2). After 7 days

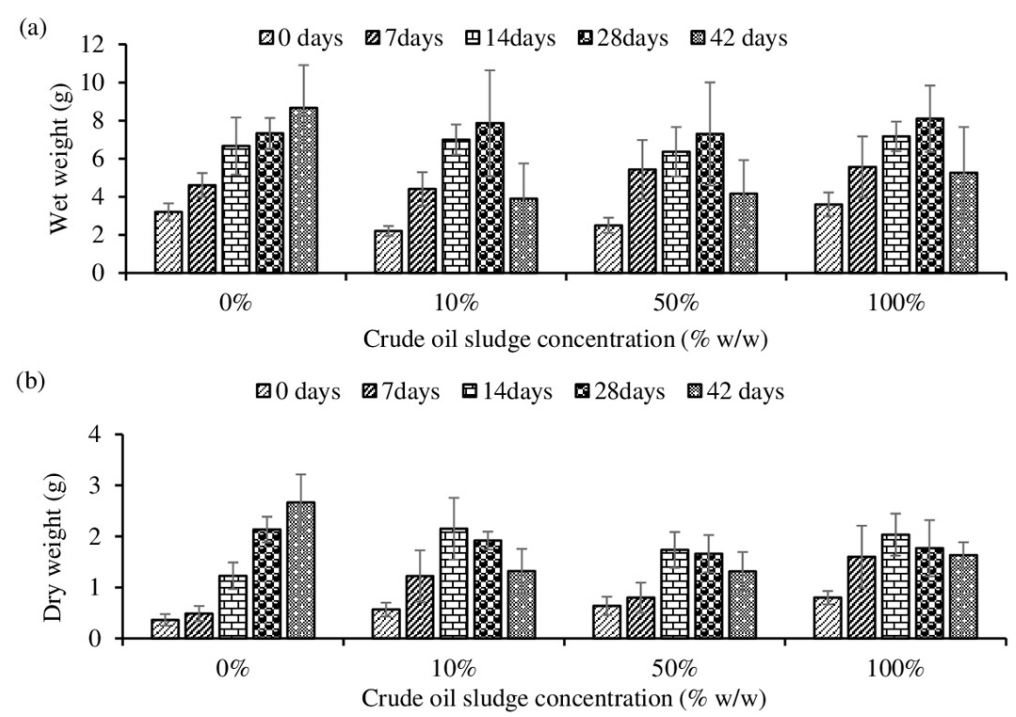

Figure 2. Growth response of L. octovalvis plants in terms of wet weight (a) and dry weight (b) in several proportionss of crude-oil-contaminated sand 
of exposure to crude oil concentration, all the plants showed high growth compared with the corresponding control treatments. At 14 days, the plant biomass increased significantly for all of the treatments until 42 days. The plants exposed to crude oil sludge proportions of $50 \%$ and $100 \%$ were found withered and yellowish. These plants exhibited an reduced growth compared with the control plants. In addition, the percentage of withered plants and that some of the leaves started to fall from the stem indicated the percentage of the whole plant affected by crude oil sludge contaminants. Consequently, the plants withered due to the toxicity effects of the crude oil sludge. The leaves turned red, and stems changed to yellow displaying signs of impaired growth compared with the control plants. According to Meudec et al. (2007), the withered and yellowish symptoms might be due to chemically stressed tissues and cells. These effects are similar to those detected by Agamuthu et al. (2010) who exposed Jatropha curcas in sands contaminated with lubricating oil. Additionally, the water content in the plant tissues was also significantly decreased due to the stressful conditions with the existence of hydrocarbons in the contaminated sands. A decrease in water content may have occurred since the presence of crude oil sludge in the sand can limit the plant access to water and oxygen (Ogbo et al. 2010). Chandra and Yadav (2010) mentioned that the contaminant can damage the tissues and membranes by reducing their metabolic transport and respiration rate. This outcome confirmed that pollutants was adsorbed and accumulated on the surface of the plant tissue. L. octovalvis growth was affected at a crude oil sludge concentration of $100 \%$, confirming that plant growth in the crude oil sludge was significantly retarded compared with the corresponding control plants. A similar result similar was also obtained by a previous study (Becerra-Castro et al. 2013). However, the plants survived healthily at crude oil sludge concentrations of $10 \%$.

\section{Concentration of cation and anion during phytotoxicity study in sand mixture}

Nutrient composition and concentration in sand are other important factors for plant growth. Sand fertility affects plant growth because mineral nutrients may be limited and fail to support plant growth (Yousuf et al. 2013). Essential nutrients can be classified according to the type of ion (cation or anion). The performance of phytotoxicity is affected by cation and anion contents of the sand. The cation concentration of potassium (K) during this study is summarized in Figure 3. Potassium is a plant nutrient that functions as a catalyst in many enzymes required for growth. It also plays an important role in regulating water use of plants (McCauley et al. 2009). In this study, K was the most abundant cation in all of the treatments $(0,10,50$ and $100 \%$ crude oil sludge concentration) and ranged from 0.24 to $0.85 \mathrm{mg} / \mathrm{kg}$, 0.5 to $0.86 \mathrm{mg} / \mathrm{kg}, 0.33$ to $0.65 \mathrm{mg} / \mathrm{kg}$ and 0.48 to $0.45 \mathrm{mg} / \mathrm{kg}$, respectively. Al-Delaimy (2013) reported that low $\mathrm{pH}$ may also reduce cation uptake due to the competition between hydrogen ions and other cations for sites on a carrier protein. Potassium is among the nutrients absorbed by plants in large quantity; this absorption is the primary form of removal in sand contaminants (Rossmann et al. 2012). The anions found in this study were nitrogen in the form of nitrate. Figure 4 shows the concentration of anions in all of the treatments. At 7 days, the percentage of $\mathrm{NO}_{3}^{-}$was high when plants were exposed to $100 \%$ crude oil sludge. The available $\mathrm{NO}_{3}{ }^{-}$ranged from 0.12 to $0.05 \mathrm{mg} / \mathrm{kg}$, 0.14 to $0.06 \mathrm{mg} / \mathrm{kg}$ and 0.15 to $0.16 \mathrm{mg} / \mathrm{kg}$ in the sand contaminated with crude oil sludge concentrations of 10,50 and $100 \%$, respectively, whereas, in the control treatment, $\mathrm{NO}_{3}^{-}$was available ranging from 0.21 to $0.05 \mathrm{mg} / \mathrm{kg}$. A decrease in

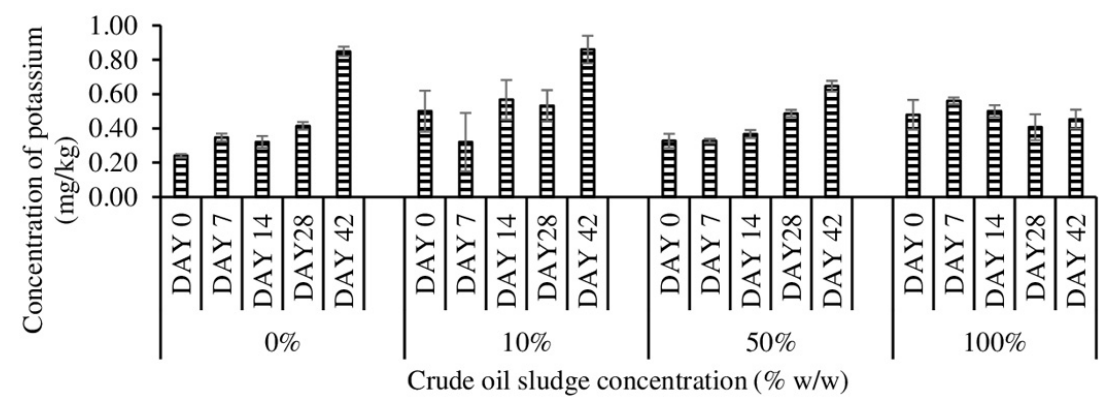

Figure 3. Concentration of potassium (cation) in crude oil sludge throughout 42-day exposure 


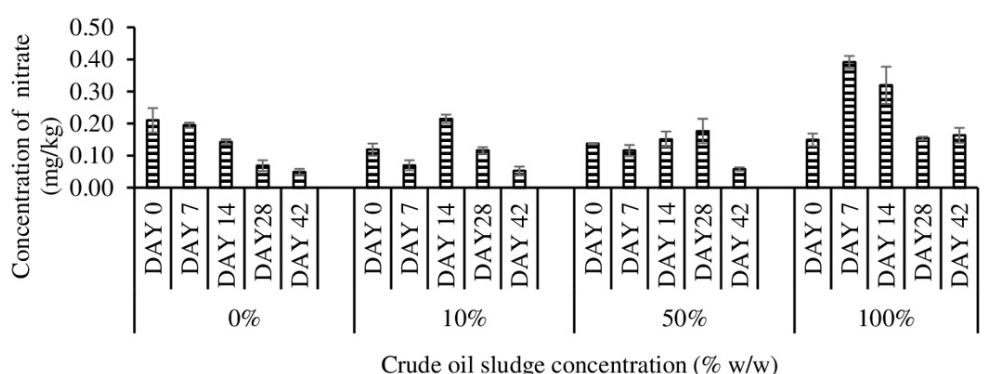

Figure 4 Concentration of nitrate (anion) in crude oil sludge throughout 42-day exposure

$\mathrm{NO}_{3}{ }^{-}$concentration was observed in all of treatments towards the end of the exposure, indicating that plants used the nitrates for their growth.

\section{Variation of hydrocarbon content in the sand mixture}

Degradation of hydrocarbon in the sand mixed with real crude oil sludge proportions was obviously detected during this study. The TPH degradation under various treatments with crude oil sludge contaminants (10, 50 and $100 \%)$ with plants and without plants during the 42-day exposure period are illustrated in Figure 5. The removal efficiency of crude oil sludge contaminants in most treatments was significantly different among the three proportions and sampling days (days 7, 14, 28 and 42). The removal of TPH was significantly increased on day 7 relative to the contaminated control without plants. On day 42 of treatment, the degrees of TPH degradation were $67.0,42.4$ and $46.2 \%$ in sand spiked with real crude oil sludge at 10,50 and $100 \%$ respectively, whereas the degradation was only 34.7 , 29.1 and $20.5 \%$ at the same respective proportions in the unplanted containers. These results proved that $L$. octovalvis can speed up the removal of petroleum hydrocarbons from real crude oil
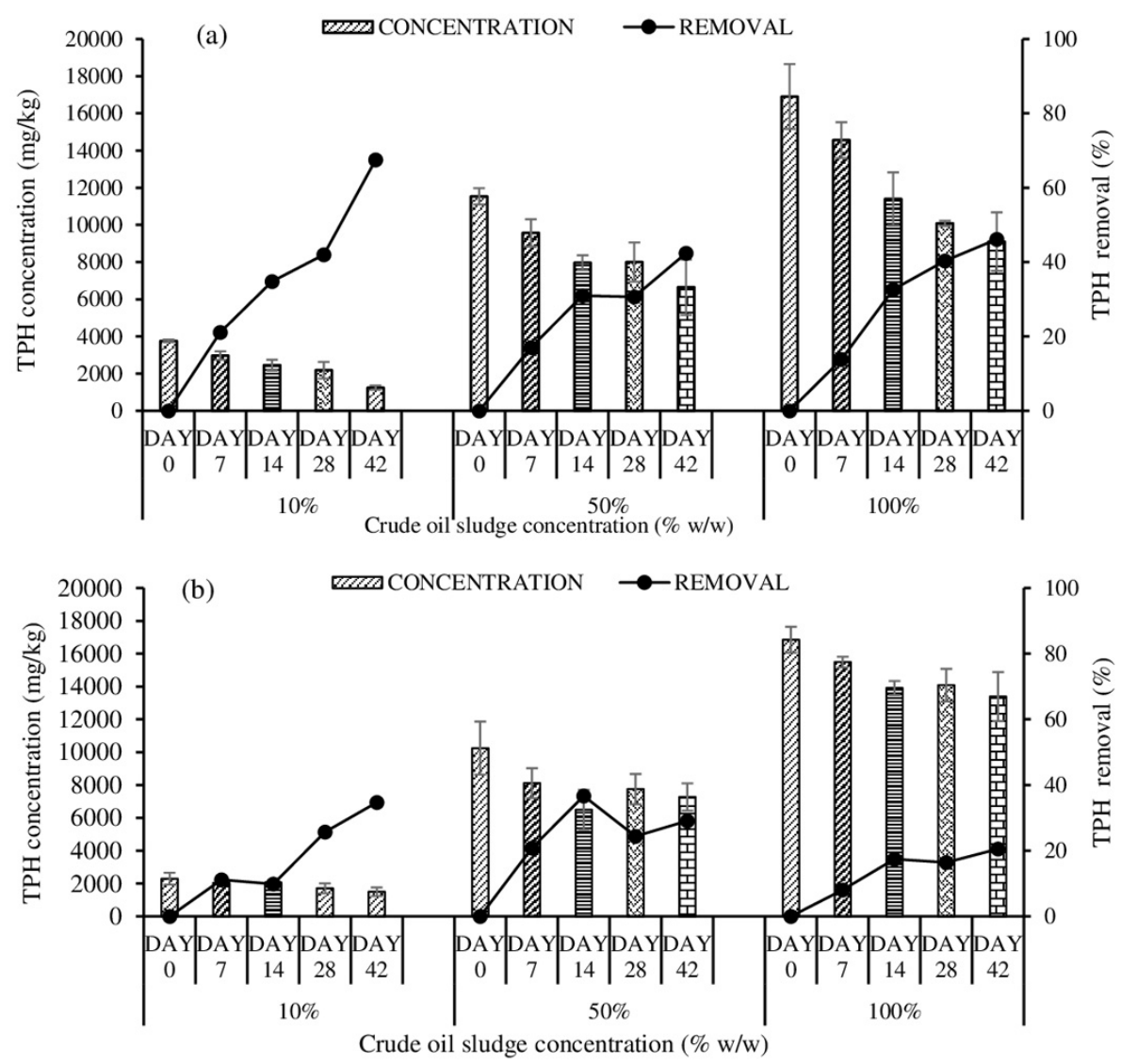

Figure 5 TPH degradation under different treatments with crude oil contaminants (10, 50 and 100\%) (a) with plants and (b) without plants during the 42 days of exposure 
sludge through the first 7 days of exposure. The highest TPH removal of $67.0 \%$ was recorded in the sand mixture exposed to a crude oil sludge proportion of $10 \%$ after 42 days of treatment, in contrast to only $34.7 \%$ removal observed in the corresponding control.

As similarly obtained by Kirk et al. (2005) and Tang et al. (2011), the TPH removal was significantly higher in the planted containers compared to the unplanted ones. The plants of $L$. octovalvis with the assistance of microbes within the roots have the capability to decrease the TPH content. Figure 6 illustrates significant differences in TPH degradation by L. octovalvis among the treatments with plants and treatments without plants for the three proportions $(10 \%, 50 \%$ and $100 \%$ ) within 42 days. The highest degradation, $67.0 \%$ was obtained at $10 \%$, whereas the average removal in its respective control treatment was only $34.7 \%$ giving evidence that $L$. octovalvis has significant effects on TPH removal from contaminated sand. A previous study used L. octovalvis to degrade $2 \mathrm{~g} / \mathrm{kg}$ gasoline in sand. The removal ratio of gasoline was $79.8 \%$ after 72 days of treatment (Al-Mansoory et al. 2017). There are many factors that affect the degradation of TPH in soil such as suitable conditions for both the plants and their associated microbes. Based on a study by White et al. (2006), the presence of microorganism such as bacteria and fungi in the rhizosphere can accelerate TPH degradation in sand. It has also been reviewed by Phillips et al. (2009) that microorganisms have significant role in the remediation of petroleum hydrocarbon-contaminated soil. Al-Sbani et al. (2016) have demonstrated that the number of PAHs degraders was significantly higher in the planted spiked soil than that in non-rhizosphere contaminated soil. According to $\mathrm{Lu}$ et al. (2010), phytodegradation is the key mechanism for TPH phytoremediation in contaminated soil. Cai et al. (2007) has defined phytodegradation as bacteria stimulation in the root zones to degrade and speed up the TPH removal. The microbe-plant interaction has successfully metabolized hydrocarbons in the planted containers. On the other hand, volatilization, eluviation, and photolysis are among the mechanisms that can degrade TPH in the unplanted soil mixture (Peng et al. 2009). They also stated that biodegradation by indigenous microorganisms had decreased the gasoline concentrations in sand.

Furthermore, there are many factors that can influence the degradation of total petroleum hydrocarbon in contaminated sites. Such factors include type of plant, physicochemical properties of the sand, contaminant loading, and nutrient accessibility. Moreira et al. (2011) highlighted that the attainment of rhizodegradation depends on the interaction of plants with their associated microorganisms, suitable environmental surroundings and the availability of contaminants. Factors of $\mathrm{pH}$, temperature, oxygen availability, microbial population in the rizhosphere, degree of plant acclimatization, nutrient accessibility, cellular transport properties of plants and chemical structure of the contaminants can also enhance biodegradation (Kotti et al. 2010; Jagtap et al. 2014). Figure 7 depicts the GC-FID chromatogram profile of hydrocarbon reduction by $L$. octovalvis for exposure to $10 \%$ of crude oil sludge in sand which indicates increasing degradation between days 0 and 42 . It suggests that $L$. octovalvis are able accelerate the degradation of crude-oil-sludge-contaminated sand. However, the interaction between these

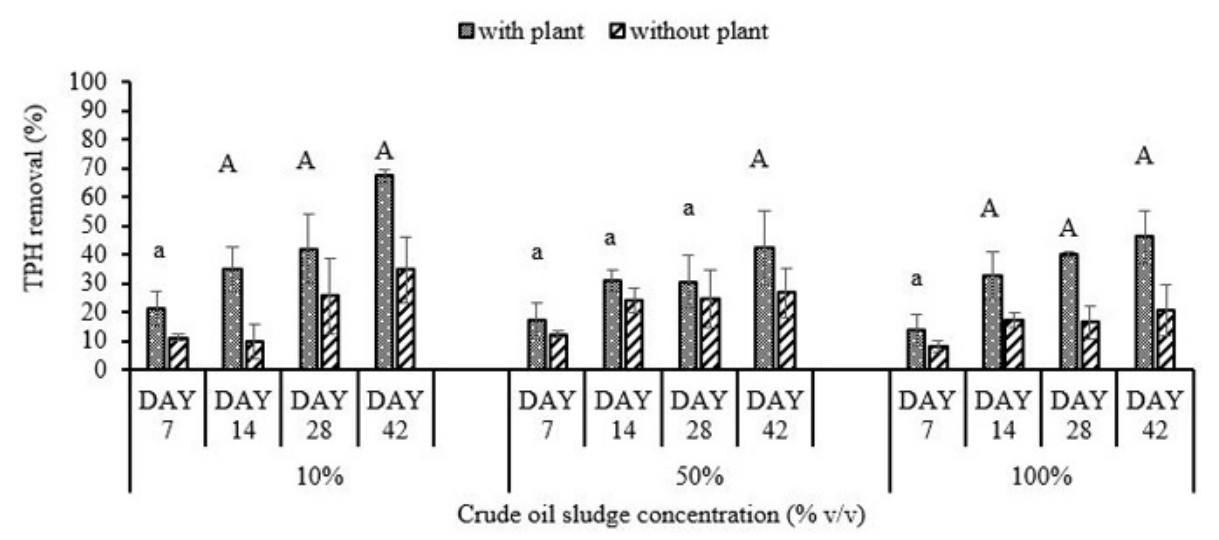

Figure 6. TPH removal by Ludwigia octavalvis under different concentration with crude oil contaminants $(10 \%, 50 \%$ and $100 \%)$ [A: significant difference at $p<0.05$ between with and without plants treatments; a: no significant difference between with and without plants treatments] 

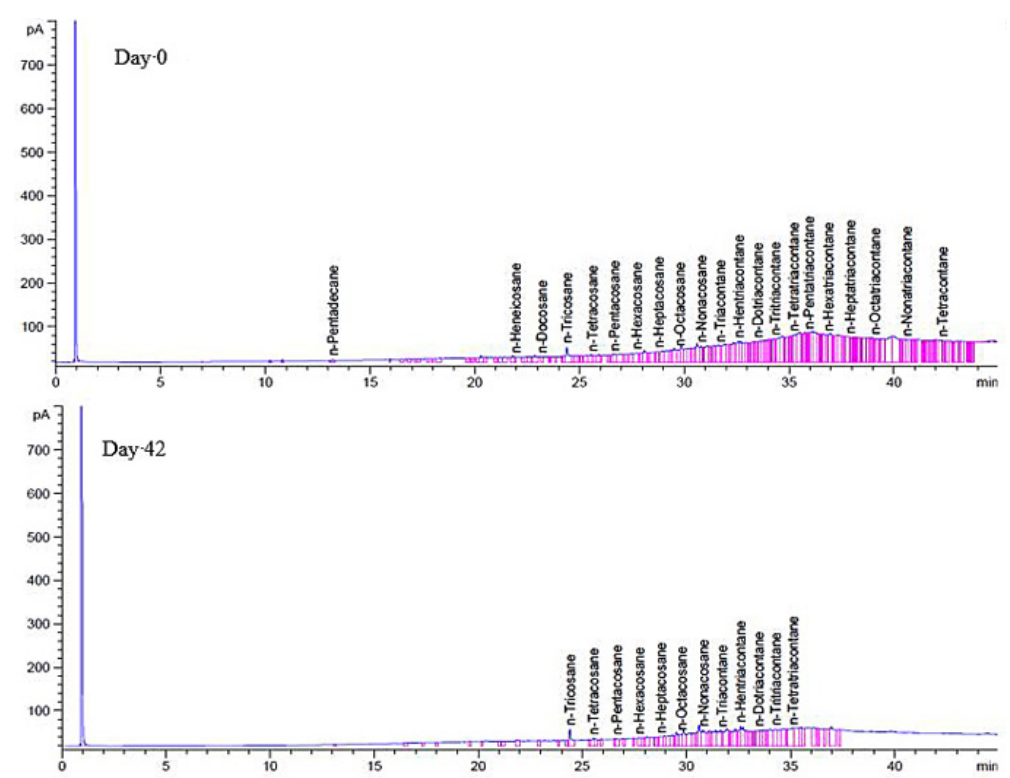

Figure 7. The GC-FID chromatogram profile of crude oil sludge degradation by L. octovalvis for exposure to $10 \%$ crude oil sludge at days 0 and 42

factors contributing to the performance of phytoremediation remains unclear and thus more detailed studies are required in future.

\section{CONCLUSIONS}

The results indicated that the removal of hydrocarbons was enhanced by the presence of L. octovalvis. It is possible that the presence of L. octovalvis roots with microorganisms has an advantageous effect on improving the degradation of total petroleum hydrocarbon pollutants. L. octovalvis shows tolerance and resistance to withstand the minimum concentration $(10,50$ and $100 \% \mathrm{v} / \mathrm{v}$ ) of used crude oil sludge in the contaminated sand. From the findings, $67.0 \%$ was recorded as the highest TPH removal in the planted containers, as compared with the corresponding unplanted containers which only achieved $34.7 \%$ removal. Generally, L. octovalvis is a potential plant species that can be effectively applied in phytoremediation of soil contaminated with crude oil sludge. This is an environmentally friendly way of treating crude oil sludge contamination and restoring sands back to their natural state.

\section{Acknowledgment}

The authors would like to thank Universiti Kebangsaan Malaysia (UKM) and also Ministry of Education Malaysia for supporting this project through FRGS/1/2019/TK02/UKM/01/1 grant.

\section{REFERENCES}

1. Alanbary, S.R.N, Abdullah, S.R.S., Abu Hassan, H. \& Othman, A.R. (2018). Screening for Resistant and Tolerable Plants (Ludwigia octovalvis and Phragmites karka) in Crude Oil Sludge for Phytoremediation of Hydrocarbons. Iranica Journal of Energy and Environment 9, 48-51.

2. Al-Baldawi, I.A.W., Abdullah, S.R.S., Abu Hasan, H., Sujá, F., Anuar, N., \& Idris, M. 2014. Optimized conditions for phytoremediation of diesel by Scirpus grossus in horizontal subsurface flow constructed wetlands (HSFCWs) using response surface methodology. Journal of Environmental Management, 140, 152-159.

3. Al-Delaimy, A.O.A. 2013. Effect of Mineral Acids on Rooting Response of Aging Mung Bean (Phaseolus aureus Roxb.) Cuttings via Indole Acetic Acid Level. Journal of Biology Agriculture and Healthcare 3(11): 40-48.

4. Agamuthu, P., Abioye, O.P. \& Abdul Aziz, A. 2010. Phytoremediation of sand contaminated with used lubricating oil using Jatropha curcas. Journal of Hazardous Materials 179, 891-894.

5. Almansoory, A.F., Abu Hasan, H., Abdullah, S.R.S., Idris, M., Anuar, N. \& Al-Adiwish, W.M. 2019. Biosurfactant produced by the hydrocarbon-degrading bacteria: Characterization, activity and applications in removing TPH from contaminated sand. Environmental Technology \& Innovation 14(2019), 1-11.

6. Al-Mansoory, A.F., Idris, M., Abdullah, S.R.S., \& Anuar N. 2017. Phytoremediation of contaminated sands containing gasoline using Ludwigia octovalvis (Jacq.) in greenhouse pots. Environmental Science and Pollution Research 24, 11998-12008. 
7. Al-Sbani, N.H., Abdullah, S.R.S., Idris, M., Abu Hasan, H., Jehawi, O.H. \& Ismail. N. I. 2016. Subsurface flow system for PAHs removal in water using Lepironia articulate under greenhouse conditions. Ecological Engineering 87, 1-8.

8. Becerra-Castro, C., Kidd, P.S., Rodríguez-Garrido, P., Monterroso, C., Santos-Ucha, P. \& PrietoFernández, A. 2013. Phytoremediation of hexachlorocyclohexane $(\mathrm{HCH})$-contaminated sands using Cytisus striatus and bacterial inoculants in sands with distinct organic matter content. Environmental Pollution 178, 202-210.

9. Cai, Q.Y., Mo, C.H, Wu, Q.T., Zeng, Q.Y., Katsoyiannis, A., \& Férard, J.F. 2007. Bioremediation of polycyclic aromatic hydrocarbons (PAHs)-contaminated sewage sludge by different composting processes. Journal of Hazardous Materials 142, 535-542.

10. Cao, Z., Liu, X., Zhang, X., Chen, L., Liu, S. \& Hu Y. 2012. Short-term effects of diesel fuel on rhizosphere microbial community structure of native plants in Yangtze estuarine wetland. Environmental Science and Pollution Research, 19, 2179- 2185.

11. Chan, H. 2011. Biodegradation of petroleum oil achieved by bacteria and nematodes in contaminated water. Separation and Purification Technology 80, 459-466.

12. Chandra, R. \& Yadav, S. 2010. Potential of Typha angustifolia for phytoremediation of heavy metals from aqueous solution of phenol and melanoidin. Ecological Engineering 36: 1277-1284.

13. Guo, H., Yao, J., Cai, M., Qian, Y., Guo, Y., Richnow, H.H., Blake, R. E., Doni, S., Ceccanti, B. 2012. Effects of petroleum contamination on sand microbial numbers, metabolic activity and urease activity. Chemosphere 87, 1273-1280.

14. Hanks, N. A., Caruso, J. A., \& Zhang, P. 2015. Assessing Pistia stratiotes for phytoremediation of silver nanoparticles and $\mathrm{Ag}(\mathrm{I})$ contaminated waters. Journal of Environmental Management 164, 41-45.

15. Hua, G., Li, J. \& Zeng, G. 2013. Recent development in the treatment of oily sludge from petroleumindustry: A review. Journal of Hazardous Materials 261, 470-490.

16. Jagtap, S. S., Woo, S.M., Kim, T. S., Dhiman, S.S., Kim, D. \& Lee, J. 2014. Phytoremediation of dieselcontaminated sand and scarification of the resulting biomass. Fuel 116, 292-298.

17. Khan, S., Afzal, M., Iqbal, S. \& Khan, Q.M. 2013. Plant-bacteria partnerships for the remediation of hydrocarbon contaminated sands. Chemosphere, 90, 1317-1332.

18. Kirk, J. L., Klironomos, J.N., Lee, H. \& Trevors, J.T (2005). "The effects of perennial ryegrass and alfalfa on microbial abundance and diversity in petroleum contaminated sand. Environmental Pollution $133,455-465$.
19. Kotti, I.P., Gikas, G.D. \& Tsihrintzis, V. A. 2010. Effect of operational and design parameters on removal efficiency of pilot-scale FWS constructed wetlands and comparison with HSF systems. Ecological Engineering 36, 862-875.

20. Liu, X., Wang, Z., Zhang, X., Wang, J., Xu, G., Cao, Z., Zhong, C. \& Su, P. 2011. Degradation of diesel-originated pollutants in wetlands by Scirpus triqueter and microorganisms. Ecotoxicology and Environmental Safety 74, 1967-1972.

21. Lu, S., Teng, Y., Wang, J. \& Sun, Z. 2010. Enhancement of pyrene removed from contaminated sands by Bidens maximowicziana. Chemosphere 81, 645-650.

22. McCauley, A., Jones, C. \& Jacobsen, J. 2009. Plant nutrient functions and deficiency and toxicity symptoms. In Nutrient Management Module No. 9. Montana State University. http://landresources.montana.edu/NM/Modules/Module9.pdf [7 Nopember 2011].

23. Meudec, A., Poupart, N., Dussauze, J. \& Deslandes, E. 2007. Relationship between heavy fuel oil phytotoxicity and polycyclic aromatic hydrocarbon contamination in Salicornia fragilis. Science Total Environmental 381, 146-156.

24. Moreira, I., Oliveira, O., Triguis, J., Santos, A., Queiroz, A., Martins, C., Silva, C. \& Jesus, R. 2011. Phytoremediation using Rhizophora mangle L. in mangrove sediments contaminated by persistent total petroleum hydrocarbons (TPHs). Microchemical Journal 99, 376-382.

25. Ogbo E.M., Tabuanu., A. \& Ubebe R. 2010. Phytotoxicity assay of diesel fuel-spiked substrates remediated with Pleurotus tuberregium using Zea mays. International Journal of Applied Research in Natural Products 3, 12-16.

26. Peng, S. Zhou, Q., Cai, Z. \& Zhang, Z. 2009. Phytoremediation of petroleum contaminated sands by Mirabilis Jalapa L. in a greenhouse plot experiment. Journal of Hazardous Materials 168(2-3), 1490-1496.

27. Phillips, L. A., Greer, C.W., Farrell, R.E., Germida, J.J. 2009. Field-scale assessment of weathered hydrocarbon degradation by mixed and single plant treatments. Applied Sand Ecology 42, 9-17.

28. Robertson, S.J., McGill, W.B., Massicotte, H.B., \& Rutherford, P.M. 2007. Petroleum hydrocarbon contamination in boreal forest sands: a mycorrhizal ecosystems perspective. Biological Reviews 82(2007), 213-240.

29. Rossmann, M., Matos, A., D., Abreu, E.C., Silva, F.F. \& Borges, A.C. 2012. Performance of constructed wetlands in the treatment of aerated coffee processing wastewater: Removal of nutrients and phenolic compounds. Ecological Engineering 49, 264-269. 
30. Sanusi, S.N.A., Helmi, M. I. E., Abdullah, S.R.S., Abu Hassan, H., Hamzah, F. M. \& Idris, M. (2016). "Comparative Process optimization of pilot scale total petroleum hydrocarbon (TPH) degradation by Paspalum scrobiculatum L. Hack using Response Surface Methodology (RSM) and Artificial Neural Network (ANN). Ecological Engineering 97: 524-534.

31. Sharonova, N.I. 2012. Tolerance of cultivated and wild plants of different taxonomy to sand contamination by kerosene. Science of the Total Environment 424, 121-129.

32. Tang, J., Wang, M., Wang, F., Sun, Q. \& Zhou, Q. 2011. Eco-toxicity of petroleum hydrocarbon contaminated sand. Journal of Environmental Sciences $23,845-851$.
33. Tang, J., Lu, Z., Sun, Q. \& Zhu, W. 2012. Aging effect of petroleum hydrocarbons in sand under different attenuation conditions. Agriculture Ecosystems and Environment 149, 109-117.

34. White, P. M., Wolf, D. J., Thomas, G. J. \& Reynolds C. M. (2006). Phytoremediation of alkylated polycyclic aromatic hydrocarbons in a crude oilcontaminated sand. Water, Air, and Sand Pollution, 169, 207-220.

35. Xu, N., Wang, W., Han, P. \& Lu, X. 2009. Effects of ultrasound on oily sludge deoiling. Journal of Hazardous Materials 171, 914-917.

36. Yousuf, M. N., Akter, S., Haque, M., Mohammad, N. \& Zaman, M.S. 2013. Compositional Nutrient Diagnosis (Cnd) Of Onion (Allium Cepa L.). Bangladesh Journal Agrilcultural Research 38, 271-287.. 